\title{
Implementation of Gender Mainstream Policy in the Implementation of the Duties and Functions of People's Representatives of the Republic of Indonesia
}

\author{
Ida Fauziyah, \\ Institut Pemerintahan Dalam Negeri, Indonesia \\ E-mail: idafauziyah@gmail.com \\ Bahrullah Akbar, \\ Institut Pemerintahan Dalam Negeri, Indonesia \\ Khasan Effendy, \\ Institut Pemerintahan Dalam Negeri, Indonesia
}

Sampara Lukman

Institut Pemerintahan Dalam Negeri, Indonesia

Received: June 11, 2020 Accepted: July 14, 2020 Online published: July 27, 2020

doi:10.5296/jpag.v10i3.17168

URL: https://doi.org/10.5296/jpag.v10i3.17168

\begin{abstract}
The research objectives are to discuss the implementation of gender mainstreaming policies in the implementation of the duties and functions of the DPR and to compile a new concept from the results of the discussion on the implementation of gender mainstreaming policies in the implementation of the tasks and functions of the Indonesian Parliament. The implementation of gender mainstreaming policies in the implementation of the duties and functions of the DPR is not yet optimal to support the realization of gender equality and justice in the life of society, nation, and state, especially to improve the position, role, and quality of women. With the Grindle public policy implementation model it can be revealed the performance of gender mainstreaming policies according to the parameters of interests affected; type of benefits; the extent of change envisioned; site of decision making;
\end{abstract}


implementor program; committed resource; power, interests, and strategies of actors involved; institution and regime characteristic; compliance and responsiveness. The new concept structured on the Strategy for Implementing Gender Mainstreaming Policies in National Development with the definition: Strategy for Implementing Gender Mainstreaming Policies in National Development is a structured strategy, tips and ways in implementing policies, programs, and activities to increase the position, role, and quality of women to realize equality and gender justice consisting of formal legality strategies, structural synergy strategies, cultural adaptation strategies, and individual strengthening strategies.

Keywords: Policy Implementation, Gender Mainstreaming, DPR Authority

\section{Introduction}

In Law Number 17 of 2014 concerning MPR, DPR, DPD, and DPRD, Article 68 states: "The DPR is a representative body of the people who are domiciled as a state institution." Article 69 states: "The DPR has the function: a. legislation; budget; and supervision. The three functions of legislation, supervision, and budget referred to are carried out within the framework of people's representation, and also to support the Government's efforts in implementing foreign policy following statutory provisions. "Article 70 states" The legislative function referred to is implemented as an embodiment of the Indonesian Parliament as the holder power forms laws. The function of the budget referred to is carried out to discuss and give approval or not give approval to the draft law on the State Budget submitted by the President. The oversight function referred to is carried out through supervision of the implementation of the law and the National Budget. In the context of implementing the legislative function, optimizing the political role of women in the DPR can be manifested by representing women's interests and at the same time emphasizing the importance of efforts to empower women and increasing women's participation in socio-economic, socio-cultural and socio-political life. This effort needs to be stated in various state policies when the legislation process is in progress. From various state policies that state the importance of women's empowerment in family life and the importance of women's participation in community life, the nation and state can develop various programs and activities to improve justice and gender equality. The effectiveness of the implementation of the programs and activities in question is certainly not only the responsibility of the executive body, but at the same time, it is also the responsibility of the legislative and judicial bodies and other state institutions. In this perspective raised the importance of optimizing the implementation of tasks and the function of the legislature in assessing the effectiveness of the implementation of gender mainstreaming policies, especially those formulated and implemented by the executive body.

In the context of the implementation of the budget function, optimizing the political role of women in the DPR can be manifested by fighting for budgetary support for women's empowerment and increasing women's participation in socio-economic, socio-cultural and socio-political life. Budget allocation support is very important for increasing and expanding women's empowerment programs and increasing women's participation in the community, nation, and state life. In this perspective, the importance of optimizing the implementation of 
the duties and functions of the legislative body was raised in assessing the effectiveness of the use of budget allocations to carry out various policies, programs, and activities to empower women in the family and to increase participation in social, national and state life, especially those implemented by executive agencies.

In the context of the implementation of the oversight function, the optimization of the political role of women in the DPR can be manifested by highlighting the critical views and attitudes of women towards the implementation of the legislation function which is the duty of each state institution, especially towards the implementation of relevant legislation with the interests of women. Thus efforts to realize gender justice and equality in the community, national, and state life are more optimal. In this perspective the importance of optimizing the implementation of the duties and functions of the legislature in carrying out oversight of the implementation of budget policies to carry out various policies, programs, and activities to empower women in the family as well as increasing women's participation in the community, national and state life, especially the budget used by institutions executive.

By carrying out the functions of representation, regulatory functions and budget functions to address the implementation of various policies, programs, and activities to empower women in the family and increase women's participation in the community, nation, and state life, then by itself, the political role of women in carrying out the duties and functions of the DPR is optimal. But the reality is not the case, because the political role of women in the implementation of government functions is still not optimal. In addition to the three government functions that are the domain of the legislative body, other government functions are the protection function, defense function, law enforcement function, development function, empowerment function, service function, and intergovernmental relations function.

Meanwhile, in a broader perspective, the suboptimal political role of women in carrying out the functions of representation and regulatory functions, among others, revealed that in general, the level of participation and representation of Indonesian women in politics and legislature was relatively low and experienced fluctuations and ups and downs. For example, in the 2014 election only produced 97 female members of the Indonesian Parliament $(17.4 \%)$ of the total 560 seats available. This figure is a decrease from the number of women who became members of the Indonesian Parliament in the 2009-2014 period which only reached 101 women $(18.1 \%$ ) compared to male members of the Indonesian Parliament which totaled 460 people $(81.9 \%)$. Even though the government has adopted an affirmative policy that requires political parties to pay attention to the level of representation of women at least 30 percent in parliament. While in the 2004 elections, the number of male Indonesian Parliament members was 489 (88.91\%) and female Indonesian Parliament members were 61 (10.7\%). In the 1999 election produced 455 male DPR members (91\%) and 45 female DPR members $(9 \%)$.

Furthermore, the results of the post-reform election gave rise to a portrait of women's representation in parliament, especially the Indonesian Parliament, which experienced dynamics and ups and downs. The largest representation of women in the DPR was in the 2009-2014 period which was 101 women (18\%) and then decreased in the 2014-2019 period 
which only amounted to 97 DPR members $(17.4 \%)$. The following data shows the number of female Indonesian Parliament members from election to post-reform election.

Table 1.1. Data on Representation of Women in Parliament Post Reformation (1999 - 2014 Period)

\begin{tabular}{ccc}
\hline Period & $\begin{array}{c}\text { Number of Members } \\
\text { of the Indonesian } \\
\text { Parliament Male }\end{array}$ & $\begin{array}{c}\text { Number of Women } \\
\text { DPR RI Members }\end{array}$ \\
\hline $1999-2004$ & $500(91 \%)$ & $45(9 \%)$ \\
$2004-2009$ & $549(89.3 \%)$ & $11(10.7 \%)$ \\
$2009-2014$ & $459(81.9 \%)$ & $101(18.1 \%)$ \\
$2014-2019$ & $463(82.6 \%)$ & $97(17.4 \%)$ \\
\hline
\end{tabular}

Sources: Public Relations of the Indonesian Parliament, 2017

The data presented in the table shows that the representation of women in the post-reform parliament, in general, is still unsatisfactory and is far from the balance of representation. A quite surprising comparison can be seen from the data on the number of female members before the reform far more than in the two post-reform periods, namely the 1999-2004 period, especially during the 2004-2009 period which experienced a drastic decline in the number of female members. The percentage of representation of women in the legislature that was put forward showed that the spirit of fulfilling a critical number of 30 percent of the number of members of parliament was not in line with expectations. Even though the 30 percent figure is expected to be the minimum number for a group in the Indonesian Parliament to be able to significantly influence decision making.

The gap in the level of representation between men and women in the legislature has more or less an impact on the policies taken by the Parliament, especially policies that concern women's affairs. Many of the legislative products produced are related to the masculine world, for example, defense, security, corruption, investment, trade, etc., compared to products that concern women, for example, matters of welfare, health, education, environment, protect children, and others. As a result, injustice in women can be seen from wage inequality between women and men workers, the high maternal mortality rate (AKI) in ASEAN, female illiteracy rates are double that of male illiteracy rates, and also the number of violence against women still high, (Edriana, et al, 2011).

The problem of women in Indonesia that has been described in the sub-condition of women in Indonesia from time to time is like an unbroken circle. It happened due to the weakness of gender-sensitive political policies and in favor of women. Policies that have not taken sides with women occur because of the low representation of women in the political process and the implementation of parliamentary functions as an arena for public policy formation. Various laws and regulations that have been made provide opportunities for women to take an active role in politics. The aforementioned laws include Article 27 of the 1945 Constitution, Law Number 12 of 2003 concerning Elections, Law Number 2 of 2008 concerning Political Parties, and Law Number 10 of 2008 concerning Elections. The appearance of women in the 
political stage in various regions shows that there is a change in the political paradigm that wants gender equality where there is a demand that women and men have equal opportunities in the political field (Vitalaya, 2009).

Law Number 2 of 2008 concerning Political Parties shows a structural commitment to affirming the involvement of women in political parties. Article 11 Paragraph (1) letter e states that "political recruitment in the process of filling political positions carried out by political parties through democratic mechanisms with due regard to gender equality and justice". In Article 2 paragraph (2) it is said that the establishment and formation of political parties include 30 percent representation of women. Paragraph (5) confirms that the management of the political parties at the central level is prepared by including at least $30 \%$ representation of women. Article 20 states that the management of political parties at the provincial and district/city levels is prepared by taking into account the representation of women at least 30 percent regulated in the AD and ART of each political party.

Regulations that affirm the involvement of women in political parties can be considered quite advanced. But the question is, to what extent do political parties consistently fulfill these obligations? That is because the patriarchal culture is still embedded in the culture of politics in Indonesia. Not all political parties have fulfilled this provision substantially. Formally, perhaps many political parties have fulfilled the affirmative provisions, but in making important policies the involvement of women has not been optimal. Other regulations that will have significant implications for women's representation in Parliament are Law Number 10 of 2008 concerning General Elections of Members of the People's Legislative Assembly, Regional Representatives Council, and the Regional People's Representative Council mandating that each political party participating in the General Election may nominate candidates for Members of the Provinces and Regency/ City Parliament for each Electoral District with at least 30 percent representation of women. This is explained in Article 53. Furthermore, Article 55 Paragraph (2) confirms that in the list of legislative candidates, every 3 (three) prospective candidates must have at least 1 (one) female candidate.

Furthermore, Law Number 2 of 2011 concerning amendments to Law Number 2 of 2008 concerning Political Parties, Article 2 paragraph (2) states that the establishment and formation of political parties include 30 percent representation of women. Women's representation is also emphasized in Article 2 paragraph (5) which reads: "Management of central political parties is prepared by including at least 30 percent representation of women." Law Number 2 of 2011 is considered to be more advanced than the previous Law (Law Law No. 2 of 2008) because it contains sanctions for political parties that violate these provisions. Article 47 paragraph (1) states that political parties that violate the above provisions will be subjected to administrative sanctions in the form of a refusal to register political parties as legal entities by the ministry. This law also emphasizes political recruitment which provides wider space for women. Article 29 paragraph (1a) states that recruitment is carried out through democratic cadre selection following the Statutes and By-Laws, taking into account at least 30 percent of women's representation.

Departing from the description of problems and opportunities to realize gender equality and 
justice and strengthen the representation of women in legislative bodies, the question is "Are there policies that promote the importance of gender equality and justice in the life of society, nation, and state?" Referring to this question, in 2000 President Abdurachman Wahid issued Presidential Instruction No. 9 of 2000 concerning Gender Mainstreaming in National Development. One of the considerations underlying the issuance of the Presidential Instruction is that to improve the position, role, and quality of women, as well as efforts to realize gender equality and justice in family, community, national and state life, it is deemed necessary to carry out gender mainstreaming strategies in the entire development process national.

Efforts to improve the position, role, and quality of women, as well as efforts to realize gender equality and justice in family, community, national, and state life are not yet optimal. This means that the implementation of Presidential Instruction No. 9 of 2000 is not yet optimal. The non-optimal implementation of the Presidential Instruction appears to be a phenomenon of the implementation of gender mainstreaming policies that can be revealed from two points of view, namely the following internal and external dimensions of women:

First, in the internal dimensions of women, quantitatively, the low representation of women in the political process and the implementation of the duties and functions of the legislative institute were revealed from the drastic reduction in the number of women legislative members. Whereas qualitatively, the low representation of women in the political process and the implementation of the duties and functions of legislative institutions may be due to the limited internal resources of women. The internal resources in question are the intellectual capacity, quality of mental attitude, and social capability of women to become trustworthy, reliable, and trusted politicians. In a broader dimension, the limitations of women's internal resources also cause the actualization of women's roles in social and economic life to be suboptimal. This situation implies that efforts to improve the position, role, and quality of women, as well as efforts to realize gender equality and justice in family, community, national, and state life have not been maximized.

Second, in the external dimension of women, some of the Laws (Laws) produced are considered discriminatory against women. One example is Law No. 44 of 2008 on Pornography which seems to criminalize a woman's body. Other laws which are also considered to have not taken into account aspects of gender justice, for example, the Marriage Law, the Law on Protection and Placement of Overseas Workers, the Fisheries Protection Act, the Law on Equality and Gender Justice, the Act on Sexual Violence, the Law on the Protection of Domestic Workers, and the Social Welfare Act. While at the regional level, Komnas Perempuan notes that there are 421 Regional Regulations (Perda) that discriminate against women. Some contents of Perda tend to disadvantage women. These local regulations generally regulate how women should dress, the separation of public space, and the application of a curfew. The policy shows that there are restrictions on the expression of women, restrictions on women's identity, and positioning of women as not equal to men. According to the authors, discriminatory treatment occurs because the policy-making process does not involve women. In a broader dimension, there are still strong beliefs, customs, traditions, and social norms that limit and even corner the position and role of women. This 
situation also implies that efforts to improve the position, role, and quality of women, especially rural women, as well as efforts to create gender equality and justice in family life and social, national and state life, are still not maximized.

\section{THEORETICAL FRAMEWORK}

Theory Framework is designed by describing the grand theory of Government Science; middle range theory Public Policy Theory; applied theory Public Policy Implementation Theory, Representation Theory, and Gender Theory. From the exploration of applied theory, it was found that driven theory is suitable as a theoretical foundation for the preparation of concepts and research instruments. Driven theory in question is the Grindle Public Policy Implementation Theory. Grindle (1980: 15) argues that the results (outcomes) of implementing policies that have a strong influence on society, individuals and groups, and the acceptance of changes are influenced by the content of the policy and the context of policy implementation. The contents of the policy include (1) interests affected; (2) type of benefits; (3) extent of change envisioned; (4) site of decision making; (5) implementer program; and (6) committed resources. The context of implementation includes (1) power, interests, and strategies of actors involved; (2) institution and regime characteristics; and (3) compliance and responsiveness. With Grindle's opinion, the next step is the Implementation of Gender Mainstreaming Policies in carrying out the duties and functions of the House of Representatives of the Republic of Indonesia conceptualized to be the implementation of Presidential Instruction No. 9 of 2000 concerning Gender Mainstreaming in National Development which is analyzed according to the content of policy and context of implementation. From the conceptual definition, nine dimensions of analysis are derived: (1) Affected Dimensions of Interest; (2) Dimensions of Type of Benefits; (3) Extent of Change Envisioned Dimension; (4) Site of Decision-Making Dimensions; (5) Dimensions of the Implementer Program; (6) Dimensions of Resource Committed; (7) Dimensions of power, interests, and strategies of actors involved; (8) Dimensions of Institution and Regime Characteristics; and (9) Dimensions of Compliance and Responsiveness. The nine dimensions of analysis were developed into $27 \mathrm{Key}$ Questions to be used as Research Informants.

The Framework is constructed by visualizing and narrating a research management system that consists of (1) Research Planning Stages that include descriptions of phenomena used as research objects, research questions, research titles, ideas of concepts and applied theories for Public Policy Implementation as elements of Input Analysis; (2) Research Implementation Stages that include Descriptive Analysis of research results developed using the Observer Triangulation Method according to the perspective of the executive officer, from the perspective of legislative members and the perspective of stakeholders as elements of Process Analysis; and (3) Stages of Reporting Research Results that include: Output Analysis are 9 Practical Implications obtained from 9 Dimensions of Analysis. Outcome Analysis is a New Concept as elements of the final results of research.

\section{Research Methods}


The research uses a qualitative research approach. Nine research informants were determined by the snowball technique. Secondary data collection from various books and documents using literature studies; Primary data collection from research informants using interview and observation techniques. Data analysis uses descriptive analysis which was developed with the analysis of the triangulation of observers.

\section{Results and Discussion}

Implementation of Gender Mainstreaming Policies in the Implementation of the Duties and Functions of DPR RI

The concept of Gender Mainstreaming (PUG) first emerged during the IV United Nations Conference for Women in Beijing in 1995. At that time, various critical areas that needed to be considered by governments and communities throughout the world to realize gender equality began to be mapped. PUG is being pushed as a strategy that must be adopted by the $\mathrm{UN}$, governments, and relevant organizations to ensure that action plans in various critical areas can be implemented effectively. According to the 1997 United Nations Economic and Social Council (ECOSOC), PUG is the process of examining influences on women and men after a plan is implemented, including legislation and programs in various fields and at all levels. PUG is a strategy to make the problems and experiences of women and men a part that is integrated with the plan, implementation, supervision, and evaluation of policies and programs in all aspects of politics, economics, social so that women and men both benefit and inequality does not continue. The ultimate goal is gender equality.

Efforts to achieve gender equality and justice have long been carried out by various parties, but they still face obstacles. Gender equality and justice are still difficult for all levels of society to enjoy, especially women. Therefore the government has adopted a policy regarding the need for an appropriate strategy that can reach all government agencies, the private sector, urban communities, rural communities, and so on. The strategy is known as Gender Mainstreaming (PUG) which comes from the English "gender mainstreaming". This strategy is contained in Presidential Instruction (Inpres) No. 9 of 2000 concerning Gender Mainstreaming in National Development. Although the government has promoted PUG, the gap between men and women is still "gaping" in various fields, including politics. Reality implies that the struggle of women to realize pro women's policies has not been carried out optimally because women's representation in politics and parliament still does not meet expectations. Not only that, although equality between women and men in Indonesia has been guaranteed in the 1945 Constitution, the reality also shows that women still experience discrimination and marginalization in various lines of life. Besides also experiencing various problems, such as acts of violence, trafficking, health problems, low education, deprivation of various rights both social, political, economic, cultural, and so forth.

In such a perspective, how is the implementation of Presidential Instruction Number 9 of 2000 concerning Gender Mainstreaming in the implementation of the tasks and functions of the Indonesian Parliament when revealed and discussed with the Grindle public policy implementation analysis approach. Grindle said, "The content of various policies also dictates the site of implementation." Furthermore, Grindle (1980: 10) said: "Decision made during 
policy formulation may also indicate who is to be charged with executing various programs, and such decisions can affect how the policy pursued. There may be, for example, differences in the capacity of various bureaucratic agencies to manage programs successfully. Some will have greater support for political elites and have greater access to resources, and some will be more able to cope with the range of demands made upon them. Besides, the form in which policy goals themselves are stated may have a decided impact on implementation." Then Grindle (1980: 15) says that "Implementing Activities are influenced by: a). Content of Policy: (1). Interest affected. (2). Type of benefits, (3). The extent of change is envisioned, (4). Site of decision making, (5). Program implementors, (6). Committed Resouces; b). Context of Implementation: (1). Power, interests, and strategies of actors involved, (2). Institution and regimen characteristic, (3). Compliance and responsiveness. Based on Grindle's theory, nine dimensions of analysis were developed: (1) Affected Interest Dimensions; (2) Dimensions of Type of Benefits; (3) Extent of Change Envisioned Dimension; (4) Site of Decision-Making Dimensions; (5) Dimensions of the Implementer Program; (6) Dimensions of Resource Committed; (7) Dimensions of power, interests, and strategies of actors involved; (8) Dimensions of Institution and Regime Characteristics; and (9) Dimensions of Compliance and Responsiveness. The conclusions from each dimension of analysis are the following:

1. From a descriptive analysis of the affected interests of the implementation of gender mainstreaming policies in the implementation of the tasks and functions of the Indonesian Parliament, the following practical implications can be drawn up:

The interests that influence the implementation of gender mainstreaming policies in carrying out the duties and functions of the People's Legislative Assembly are not limited to the political interests of women. Because the implementation of the duties and functions of the House of Representatives are also involved in the administration of a government management system, functionally and situational factors affecting the implementation of gender management policies can include socio-cultural interests, socioeconomic interests and socio-political interests that are closely related to the position, role, and capacity of women in various sectors and levels. Therefore, the implementation of gender mainstreaming policies in national development needs to be increased and expanded to achieve all the objectives of women's resource development; and carried out in the context of the development of the Whole Indonesian People and Building the Entire Indonesian Community.

2. From a descriptive analysis of the Type of Benefits of implementing gender mainstreaming policies in the implementation of the tasks and functions of the Indonesian Parliament, the following practical implications can be drawn up:

The diversity of the benefits of gender mainstreaming policies is fairly numerous and can touch all parties. However, the collective awareness of the importance of gender equality and justice has not been the motivation of all Indonesian Parliament Members in managing the benefits of gender mainstreaming policies. Because increasing the position, role and quality of women to realize gender equality and justice is a joint effort that is closely related to the common interests of all the nation's children, including the interests 
of all Members of Parliament, the invitation to jointly increase efforts to realize gender equality and justice following their position, function, each potential is worth following. For this reason, it is necessary to consolidate resources and efforts to optimize the implementation of gender mainstreaming policies in various fields of life.

3. From the descriptive analysis of the extent of change envisioned through the implementation of gender mainstreaming policies in the implementation of the tasks and functions of the Indonesian Parliament, the following practical implications can be drawn up:

The degree of change reflected in implementing gender mainstreaming policies in the implementation of the duties and functions of the Indonesian Parliament is reducing the gap between women and men in accessing and controlling resources, participating in development, in making decisions, and in benefiting from development policies and programs. More broadly, gender justice is created which shows no more discrimination against women, no more labeling to a person or group of women based on a wrong assumption; violence does not occur again to women; and the assessment that a role performed by women is lower than that of men. Therefore, a clear shared vision and mission are needed to optimize the implementation of gender mainstreaming policies in national development.

4. From a descriptive analysis of the site of decision making through the implementation of gender mainstreaming policies in the implementation of the tasks and functions of the Republic of Indonesia Parliament, Practical Implications can be drawn up as follows:

Quite a lot of political decisions are taken by women politicians in parliament. Political decisions mainly taken by women politicians in Commission VIII aim to support the implementation of policies, programs, and activities to improve the position, role, and quality of women to realize gender equality and justice, especially those implemented by the Ministry of Women's Empowerment and Child Protection. Thus the role of women politicians in the process of implementing gender mainstreaming policies through the implementation of the duties and functions of the Indonesian Parliament is in the position of making political decisions. The political decision also determines the direction of policy and efforts to strengthen the position, role, and quality of women needed to support the realization of gender equality and justice. Therefore, the role of women politicians in the process of implementing gender mainstreaming policies that are already in the decision-making position needs to be optimized.

5. From a descriptive analysis of program implementers through implementing gender mainstreaming policies in the implementation of the tasks and functions of the Indonesian Parliament, Practical Implications can be drawn up as follows:

There are quite a lot of national development programs aimed at improving the position, role, and quality of women to realize gender equality and justice. A national development program specifically focused on efforts to empower women is carried out by the Ministry of Women's Empowerment and Child Protection. The implementation of the duties and 


\section{Macrothink}

Journal of Public Administration and Governance

ISSN 2161-7104

2020, Vol. 10, No. 3

functions of the Indonesian Parliament in the implementation of the national program is carried out by Members by being critical and corrective as well as providing support for budget allocation agreements for each gender mainstreaming program. The intended program among others is revealed from the performance of development programs in the health, education, labor, and legal fields. In the context of the implementation of the government management system, the implementation of Presidential Instruction Number 9 of 2000 functionally clearly links the executive function with the legislative function in a unified governance management system. The government management system is technically carried out by members of the Indonesian Parliament Commissions and their partners by compiling and agreeing on programs and budget allocations to improve the position, role, and quality of women. Therefore, the performance of partnerships between the government and the Parliament in implementing gender mainstreaming policies needs to be improved and expanded.

6. From a descriptive analysis of resource commitments through the implementation of gender mainstreaming policies in the implementation of the tasks and functions of the Indonesian Parliament, Practical Implications can be drawn up as follows:

The commitment of resources to implement national development programs aimed at improving the position, role, and quality of women to realize gender equality and fairness is quite optimal. The stated resource commitments were revealed among others from the support of budget resources agreed by the Government and the Parliament for each fiscal year as well as the implementation instructions and technical instructions for the preparation of gender-responsive budgeting by the Minister of Finance, and the roadmap for gender mainstreaming in national development prepared by the National Development Planning Agency. For this reason, the Ministry of Women's Empowerment and Child Protection is expected to be the leading sector in the implementation of Presidential Instruction Number 9 of 2000.

7. From a descriptive analysis of the power, interests, and strategies of the parties involved (power, interests, and strategies of actors involved) the implementation of gender mainstreaming policies in the implementation of the duties and functions of the Indonesian Parliament, the Practical Implications can be drawn up as follows:

The power, interests, and strategies of the parties involved in implementing gender mainstreaming policies in the implementation of the duties and functions of the Indonesian Parliament are quite diverse and very broad. The powers, interests, and strategies of the parties concerned are revealed according to the position, roles, and responsibilities of each party. From the expression of the parties' strategies, four gender mainstreaming strategies can be noted that can be developed to optimize the implementation of gender mainstreaming policies. The four gender mainstreaming strategies in question are personal strategy, cultural strategy, structural strategy and formal legal strategy as a system of raising and utilizing resources to improve the position, role, and quality of Indonesian women to realize gender equality and justice that meet the needs of the people's welfare. For this reason, it is necessary to improve and expand the 
strategy of raising and utilizing resources to improve the position, role, and quality of Indonesian women to realize gender equality and justice.

8. From a descriptive analysis of the institution and regime characteristics of the implementation of gender mainstreaming policies in the implementation of the duties and functions of the Indonesian Parliament, the Practical Implications can be drawn up as follows:

The characteristics of the ruling institutions or regimes in each period of government are equally issuing policies that consider gender equality and justice important, but differ in terms of the intensity and focus of the policy implementation. Among several periods of government, especially governance in the reform era, President Abdurachman Wahid appeared more prominent in showing the priorities, intensity, and focus of gender mainstreaming policies. This was revealed from President Abdurachman Wahid's Instruction No. 9 of 2000 concerning Gender Mainstreaming in National Development. One of the considerations in the issuance of the Inpres is that to improve the position, role, and quality of women, as well as efforts to realize gender equality and justice in family, community, national and state life, it is deemed necessary to carry out gender mainstreaming strategies in the entire national development process. Therefore, efforts are needed to improve the position, role, and quality of women that are sustainable to realize gender equality and justice.

9. From a descriptive analysis of efforts to meet and respond (compliance and responsiveness) to the various aspirations and expectations of various parties through the implementation of gender mainstreaming policies in the implementation of the duties and functions of the Indonesian Parliament, the Practical Implications can be drawn up as follows:

Efforts to meet and respond to the various aspirations and expectations of various parties for the performance improvement of the position, role, and quality of women to realize gender equality and justice are carried out by stakeholders through the implementation of various national development policies, programs, and activities. The various national development policies, programs, and activities, among others, are carried out through partnership forums between the Government and the Indonesian Parliament at various levels of government. Thus the process of implementing gender mainstreaming policies in the implementation of the duties and functions of the Indonesian Parliament is one of the lever factors and at the same time encourages efforts to improve the position, role, and quality of Indonesian women for the realization of gender equality and equality. Therefore, it is necessary to increase the effectiveness of the implementation of gender mainstreaming policies in the implementation of the duties and functions of the Indonesian Parliament.

New Concepts from the Discussion of the Implementation of Gender Mainstreaming Policies in National Development

The new concept is the result of the development of theory which is used as a theoretical 
basis for the preparation of research concepts. The new concept is based on empirical findings obtained from the discussion of the results of interviews with research informants. The new concepts gained are as follows:

Theoretical Basis: Grindle (1980: 15) argues that the outcomes of policy implementation that have a strong influence on society, individuals and groups, and the acceptance of change are influenced by the content of the policy and the context of policy implementation. The contents of the policy include (1) interests affected; (2) type of benefits; (3) extent of change envisioned; (4) site of decision making; (5) implementer program; and (6) committed resources. The context of implementation includes (1) power, interests, and strategies of actors involved; (2) institution and regime characteristics; and (3) compliance and responsiveness. With Grindle's opinion, the next step is the Implementation of Gender Mainstreaming Policies in carrying out the duties and functions of the House of Representatives of the Republic of Indonesia conceptualized to be the implementation of Presidential Instruction Number 9 of 2000 concerning Gender Mainstreaming in National Development which is analyzed according to the content of policy and context of implementation.

Empirical Basis: Based on the flow of disclosure and discussion of the power, interests, and strategies of the parties involved (power, interests, and strategies of actors involved) the implementation of gender mainstreaming policies in the implementation of the tasks and functions of the Republic of Indonesia Parliament obtained empirical findings (research finding) as follows:

The power, interests, and strategies of the parties involved in implementing gender mainstreaming policies in the implementation of the duties and functions of the Indonesian Parliament are quite diverse and very broad. The powers, interests, and strategies of the parties concerned are revealed according to the position, roles, and responsibilities of each party. From the expression of the parties' strategies, four gender mainstreaming strategies can be noted that can be developed to optimize the implementation of gender mainstreaming policies. The four gender mainstreaming strategies in question are personal strategy, cultural strategy, structural strategy and formal legal strategy as a system of raising and utilizing resources to improve the position, role, and quality of Indonesian women to realize gender equality and justice that meet the needs of the people's welfare. For this reason, it is necessary to improve and expand the strategy of raising and utilizing resources to improve the position, role, and quality of Indonesian women to realize gender equality and justice.

New Concept: New Concept is the result of the development of a theory that is used as a theoretical foundation for the preparation of research concepts. The New Concept compiled from the results of the discussion of the implementation of gender mainstreaming policies in the implementation of the tasks and functions of the Indonesian Parliament is a New Concept on the Strategy for Implementing Gender Mainstreaming Policies in National Development with the definition: Strategy for Implementing Gender Mainstreaming Policies in National Development the process of implementing policies, programs and activities to improve the position, role and quality of women for the realization of gender equality and justice 
consisting of formal legality strategies, structural synergy strategies, cultural adaptation strategies, and individual strengthening strategies. From this definition four strategies are developed: (1) Dimensions of the Formal Legality Strategy; (2) Dimension of Structural Synergy Strategy; (3) Dimensions of Cultural Adaptation Strategies; and (4) Dimensions of Individual Strengthening Strategies. Description: The four dimensions of gender mainstreaming strategies include the following descriptions:

The Formal Legality Strategy is a structured strategy, tips and ways to realize the performance of formulation, implementation and evaluation of laws and regulations that are responsive to gender issues at various sectors and levels. Application of the Formal Legality of Gender Mainstreaming Strategy to formally aim at realizing gender equality and justice in various sectors and levels. To achieve these objectives a comprehensive and integrated approach is made to mobilize and utilize all resources, especially legal resources and professional resources, to improve the position, role and capacity of women in the socio-cultural life order, the socio-economic life order and the social life order political. Achievements of the Formal Legality of Gender Mainstreaming Strategy include (1) Key Performance Indicators for policy formulation that are responsive to gender issues; (2) Key Performance Indicators for implementing policies that are responsive to gender issues; and Key Performance Indicators evaluating policies that are responsive to gender issues at various sectors and levels.

Structural Synergy Strategy is a strategy, tips and structured way to improve and expand functional integration, operational direction, and conditional alignment between government agencies and between government bureaucracy work units in implementing policies, programs and activities of national development related to improving position, the role and capacity of women. Implementation of the Structural Synergy Strategy in Gender Mainstreaming to formally aim at realizing gender equality and justice in various sectors and levels. To achieve this goal a comprehensive and integrated approach is taken to mobilize and utilize all resources to improve the position, role and capacity of women through the implementation of government functions. The intended government functions include the protection function, the representative function, the regulatory function, the development function, the empowerment function, and the service function. Achievements of the Structural Synergy Strategy for Gender Mainstreaming include (1) Indicators for the Protection of Women, (2) Indicators for Women's Representation, (3) Indicators for Regulating Women, (4) Indicators for Women's Development, (5) Indicators for Women's Empowerment, and (6) Indicators for Women Services in various sectors and levels.

The Cultural Adaptation Strategy is a structured strategy, tips and ways to adjust cultural and cultural values related to the position, role and capacity of women in family life, social life, economic activities and political activities. Implementation of the Cultural Adaptation Strategy for Gender Mainstreaming to formally aim at realizing gender equality and justice in various sectors and levels. To achieve these objectives a comprehensive and integrated approach is made to mobilize and utilize all resources to improve the position, role and capacity of women in family life, social life, economic activities and political activities. The achievements of the Cultural Adaptation Strategy for Gender Mainstreaming include (1) 
Family Life Indicators, (2) Social Life Indicators, (3) Economic Activity Indicators and (4) Political Activity Indicators. at various levels.

The Individual Strengthening Strategy is structured, tips and ways to strengthen women's internal resources which include physical health, intellectual capacity, quality of mental attitude and social capabilities. Implementation of Individual Strengthening Gender Mainstreaming to formally aim to improve the position, role and capacity of women to realize gender equality and justice in various sectors and levels. To achieve these objectives a comprehensive and integrated approach is made to mobilize and utilize all resources to improve the position, role and capacity of women in family life, social life, economic activities and political activities. Achievements for Strengthening Individual Gender Mainstreaming include (1) Physical health indicators, (2) Indicators of intellectual capacity, (3) Indicators of mental attitude quality, and (4) Indicators of social capability.

Proposition: From the description of the new concepts put forward, propositions are made: Formal legality strategies, structural synergy strategies, cultural adaptation strategies, and individual strengthening strategies determine the effectiveness of implementing gender mainstreaming policies.

\section{Closing}

The implementation of gender mainstreaming policies in the implementation of the tasks and functions of the Indonesian Parliament is optimal enough to support the realization of gender equality and justice in the life of society, nation and state, especially to improve the position, role and quality of women in all sectors and levels. The implementation of the duties and functions of the DPR RI is one of the determining factors in the success of implementing gender mainstreaming policies in national development. This was revealed among others from some legislative products that were more responsive to gender issues, more women representatives in parliament, the existence of budget support agreed by the Government and Parliament for each fiscal year, there were implementation instructions and technical instructions for preparing gender-responsive budgeting by the Minister of Finance, and a roadmap for gender mainstreaming in national development prepared by Bappenas. Using the Grindle public policy implementation model approach, it is revealed that the performance of gender mainstreaming policies in carrying out the duties and functions of the DPR RI is as followS: Interests affected: The interests that influence the implementation of gender mainstreaming policies in the implementation of the duties and functions of the DPR are not limited to the political interests of women. Because the implementation of the duties and functions of the DPR is also involved in the administration of a government management system, functionally and situational factors affecting the implementation of gender mainstreaming policies can include socio-cultural interests, socioeconomic interests and socio-political interests that are closely related to position, the roles and capacities of women in various sectors and levels. Type of benefits: The diversity of benefits of gender mainstreaming policies is fairly numerous and can touch all parties. However, the collective awareness of the importance of gender equality and justice has not been the motivation of all DPR Members in managing the benefits of gender mainstreaming policies. Because 
increasing the position, role and quality of women to realize gender equality and justice is a joint effort that is closely related to the common interests of all the nation's children, including the interests of all Members of Parliament, the invitation to jointly increase efforts to realize gender equality and justice following their position, function, each potential is worth following. Extent of change envisioned: The degree of change reflected in the implementation of gender mainstreaming policies in the implementation of the duties and functions of the DPR is the reduction in gaps between women and men in accessing and controlling resources, in participating in development, in decision making, and in benefiting from policies and development program. More broadly, a gender justice is created which shows no more discrimination against women, no more labeling to a person or group of women based on a wrong assumption; violence does not occur again to women; and the assessment that a role performed by women is lower than that of men. Site of decision making: Quite a lot of political decisions are taken by women politicians in parliament. Political decisions mainly taken by women politicians in Commission VIII aim to support the implementation of policies, programs and activities to improve the position, role and quality of women to realize gender equality and justice. Thus the role of women politicians in the process of implementing gender mainstreaming policies through the implementation of the duties and functions of the DPR is in the position of making political decisions. The political decision also determines the direction of policy and efforts to strengthen the position, role and quality of women needed to support the realization of gender equality and justice. Program implementers: There are quite a lot of national development programs aimed at improving the position, role and quality of women to realize gender equality and justice. A national development program specifically focused on efforts to empower women is carried out by the Ministry of PPPA. The implementation of the duties and functions of the DPR in the implementation of the national program is carried out by Members by being critical and corrective as well as providing support for budget allocation agreements for each gender mainstreaming program. The intended program among others is revealed from the performance of development programs in the health, education, labor and legal fields. In the context of the implementation of the government management system, the implementation of Presidential Instruction Number 9 of 2000 functionally clearly links the executive function with the legislative function in a unified governance management system. The government management system is technically carried out by members of the DPR Commissions and their partners by compiling and agreeing on programs and budget allocations to improve the position, role and quality of women. Resource committed: Commitment of resources to implement national development programs aimed at improving the position, role and quality of women to realize gender equality and fairness is quite optimal. The stated resource commitment was revealed among others from the support of budget resources agreed by the Government and the Parliament for each fiscal year as well as the implementation instructions and technical guidelines for the preparation of gender-responsive budgeting by the Minister of Finance, and the roadmap for gender mainstreaming in national development prepared by Bappenas. Power, interests, and strategies of actors involved: The power, interests and strategies of the parties involved in the implementation of gender mainstreaming policies in the implementation of the duties and functions of the DPR are quite diverse and 
very broad. The powers, interests and strategies of the parties are actualized according to the position, roles and responsibilities of each party. Four strategies for gender mainstreaming are noted to optimize the implementation of gender mainstreaming policies, namely personal strategies, cultural strategies, structural strategies and formal legality strategies. Institution and regime characteristics: The characteristics of the institutions or regimes in power in each period of government are equally issuing policies that consider gender equality and justice important, but differ in terms of the intensity and focus of the policy implementation. Among several periods of government, especially governance in the reform era, President Abdurachman Wahid appeared more prominent in showing the priorities, intensity and focus of gender mainstreaming policies. This was revealed from President Abdurachman Wahid's Instruction No. 9 of 2000 concerning Gender Mainstreaming in National Development. One of the considerations in the issuance of the Inpres is that to improve the position, role and quality of women, as well as efforts to realize gender equality and justice in family, community, national and state life, it is deemed necessary to carry out gender mainstreaming strategies in the entire national development process. Compliance and responsiveness: Efforts to meet and respond to the various aspirations and expectations of various parties for the performance improvement of the position, role and quality of women to realize gender equality and justice are carried out by stakeholders through the implementation of various national development policies, programs and activities. The various national development policies, programs and activities, among others, are carried out through partnership forums between the Government and the DPR at various levels of government. Thus the process of implementing gender mainstreaming policies in the implementation of the duties and functions of the DPR is one of the lever factors and at the same time encourages efforts to improve the position, role and quality of Indonesian women for the realization of gender equality and equality.

The new concept which is composed of the results of the discussion on the Implementation of Gender Mainstreaming Policies in the implementation of the tasks and functions of the Indonesian Parliament is a New Concept on the Implementation Strategy of Gender Mainstreaming Policies in National Development with the definition: Strategy for Implementing Gender Mainstreaming Policies in National Development structured in the implementation of policies, programs and activities to improve the position, role and quality of women for the realization of gender equality and justice consisting of formal legality strategies, structural synergy strategies, cultural adaptation strategies, and individual strengthening strategies. From this definition four strategies are developed: (1) Dimensions of the Formal Legality Strategy; (2) Dimension of Structural Synergy Strategy; (3) Dimensions of Cultural Adaptation Strategies; and (4) Individual Strengthening Strategy.

\section{Reference}

Aida, V. (2009). Evaluasi Pengaruh Utama Gender di Sektor Koperasi, Usaha Kecil, Mikro, Menengah (UMKM), di Publikasikan oleh Bappenas Kementerian Pemberdayaan Perempuan RI Jakarta: Pustaka Pelajar.

Grindle, M. S. (1980). Politics and Policy Implementation in the Third World, Princeton 
University Press, New Jersey.

Hubeis, A. V. S. (2010). Pemberdayaan perempuan dari masa ke masa. IPB press.

Lawrence Neuman, W. (2003). Social Research Methods Qualitative and Quantitative Approach, Allyn and Bacon: London.

Neuman, W. L. (1997). Social Research Methods, London: Needham Heights, Allyn and Bacon.

Pini, B., \& McDonald, P. (2011). Women and Representation in Local Government International case studies, Routledge Research in Comparative Politics, by Routledge 2 Park Square, Milton Park, Abingdon, Oxon OX14 4RN

\section{Copyright Disclaimer}

Copyright for this article is retained by the author(s), with first publication rights granted to the journal.

This is an open-access article distributed under the terms and conditions of the Creative Commons Attribution license (http://creativecommons.org/licenses/by/4.0/). 